\title{
MELBOURNE, AUSTRALIA
}

\section{HUMAN RIGHTS LAW RESOURCE CENTRE}

\section{HUMAN RIGHTS DINNER}

\author{
Saturday $29^{\text {th }}$ April 2006
}

\section{Taking Economic, Social and Cultural Rights Seriously}

\section{Professor Paul Hunt}

(UN Special Rapporteur on the right to the highest attainable standard of health; University of Waikato, New Zealand; University of Essex, UK)

The last few years have seen some remarkable developments in the field of international human rights. For some decades, the international community focussed on classic civil and political rights - the prohibition against inhumane treatment, the right to a fair trial, freedom of speech, and so on. But, since the late 1990s, the international community has begun to devote more attention to economic, social and cultural rights - the rights to education, food and shelter, as well as the right to the highest attainable standard of physical and mental health. ${ }^{1}$

The Council of Europe, for example, has established a complaints process for economic, social and cultural rights that is beginning to generate some interesting jurisprudence. $^{2}$ The first case led to a finding that Portugal was taking inadequate measures to combat child labour. ${ }^{3}$

The human rights system that covers the Americas is also taking economic, social and cultural rights more seriously. In a recent case, the Inter-American Commission on Human Rights - which is based in Washington DC - held that El Salvador was obliged to provide antiretroviral medication to a group of petitioners with HIV/AIDS. ${ }^{4}$

\footnotetext{
${ }^{1}$ The literature is now voluminous. A good place to start is A. Eide et al (eds.), Economic, Social and Cultural Rights, $2^{\text {nd }}$ ed., Kluwer, 2001.

${ }^{2}$ The Additional Protocol to the European Social Charter Providing for a System of Collective Complaints, Council of Europe, 1995.

${ }^{3}$ International Commission of Jurists v Portugal, Complaint No. 1/1998, European Committee of Social Rights (date of report to Committee of Ministers, 9 September 1999).

${ }^{4}$ Jorge Odir Miranda Cortez et al v El Salvador, Report No. 29/01, Inter-American Commission on Human Rights, 7 March 2001.
} 
The same trend is apparent in the African regional human rights system. For example, the African Commission on Human and Peoples' Rights found a breach of the right to health and a safe environment where the extraction of oil reserves had contaminated the environment damaging the health of local communities. ${ }^{5}$

This renewed attention to economic, social and cultural rights is not confined to regional human rights systems, it also extends to the human rights system of the United Nations. For example, the UN has recently appointed a number of independent experts - Special Rapporteurs - on the rights to education, housing, food and health, to help States better promote and protect these rights. ${ }^{6}$ Before 1998, there were numerous Special Rapporteurs on civil and political rights - but not one on an economic, social or cultural right.

Moreover, this trend is not confined to the regional and UN human rights systems - it encompasses some national jurisdictions, too.

A couple of years ago, Norway incorporated into its domestic law the UN's main treaty on economic, social and cultural rights. As is well known, South Africa has placed economic, social and cultural rights in its Constitution and rendered them justiciable, generating some important case law on the rights to shelter and health. ${ }^{7}$ The Indian courts continue to adjudicate on economic, social and cultural rights by reading them into classic civil and political rights. ${ }^{8}$ Finland recently adopted an interesting approach: it constitutionalised some economic, social and cultural rights in brief one-sentence formulations with the explicit intention of elaborating these rights in more detailed legislation. ${ }^{9}$ In the United Kingdom, some judges are beginning to interpret the new Human Rights Act - which is a classic catalogue of civil and

\footnotetext{
${ }^{5}$ The Social and Economic Rights Action Center for Economic and Social Rights v Nigeria, African Commission on Human and Peoples' Rights, Communication No. 155/96 (2001).

${ }^{6}$ All have produced a number of UN reports that endeavour to deepen understanding of the rights within their mandates. My reports, press statements and various presentations can be found at http://www2.essex.ac.uk/human_rights_centre/rth/

${ }^{7}$ For example, Minister of Health and others $v$ Treatment Action Campaign and others, (2002) 5 SA 721.

${ }^{8}$ For example, Paschim Banga Khet Samity v State of West Bengal, (1996) 4 SCC 37.

${ }^{9}$ See Paul Hunt, Reclaiming Social Rights: International and Comparative Perspectives, Dartmouth, 1996, pp 30 and 51.
} 
political rights - in such a way that they tend to reinforce elements of economic, social and cultural rights. ${ }^{10}$

The same trend can be seen in civil society.

Today, in every region of the world, including in the United States, civil society groups are organising around economic, social and cultural rights. They have understood that all human rights - civil, political, economic, social and cultural - are tools for tackling unfairness and disadvantage. Long-established international human rights organisations, like Amnesty International and Human Rights Watch, which have historically focussed on civil and political rights, have recently added some elements of economic, social and cultural rights to their agendas.

On my visits overseas, I am sometimes astonished by a civil society's fluency and familiarity with economic, social and cultural rights. In some countries, civil society groups actively organise around these human rights. In Peru, they recently demonstrated in the streets demanding that the trade agreement with the United States must not jeopardise access to essential medicines for those living in poverty. Access to essential drugs became a significant issue in the recent presidential elections in Peru. They are not yet demonstrating in the streets of London, but later this year a British non-governmental organisation is publishing the first book-length audit of economic and social rights in the United Kingdom. ${ }^{11}$

Of course this trend - the trend to take economic, social and cultural rights more seriously - is contested and uneven. But in my view the general trend is unmistakeable. Economic, social and cultural rights are on a rising tide.

A few years ago, I spent quite a bit of time arguing that economic, social and cultural rights are indeed fundamental human rights.

\footnotetext{
${ }^{10}$ For example, $R v$ Secretary of State for the Home Department ex parte Adam, (2005) UKHL 66 (entitled $R$ on the application of Limbuela before the Court of Appeal).

${ }^{11}$ Written and edited by Stuart Weir, Director of the Democratic Audit, Methuen is scheduled to publish this audit in September 2006.
} 
I used to point out that these rights are recognised as fundamental human rights in a host of binding international treaties - and that the rights to basic shelter and health protection are just as important to a our well-being and dignity as the rights to freedom of assembly and expression - and that all these human rights are actually interlocking and mutually reinforcing.

Today, I rarely have to use those arguments.

A few years ago I also spent quite a bit of time arguing that there is nothing intrinsically non-justiciable about economic, social and cultural rights. A society is free to decide what it wants its courts to adjudicate upon. If a society wishes its courts to adjudicate upon issues of detention, expression, privacy, shelter and the adequacy of health services - there is no jurisprudential reason why it should not. It might not wish, for political reasons, to give some of those tasks to the courts - but that is entirely different from saying that those issues are somehow incapable of judicial determination.

Today, these arguments need less attention - mainly because so many reputable tribunals in so many jurisdictions adjudicate, on a regular basis, across the whole range of human rights, including economic, social and cultural rights. The record speaks for itself.

Can I briefly mention one sleight of hand that is sometimes used when discussing these issues?

The argument goes - it is appropriate for a court to adjudicate on, say, inhumane treatment because it can simply tell those responsible to stop the abusive treatment.

And the argument continues - it is inappropriate for a court to adjudicate on, say, shelter because this may require the court to make an order that has fiscal implications and that is the job of the legislature, not the judiciary.

In my view, this argument is misleading. 
It is true, inhumane treatment sometimes requires a court to simply say - 'no, stop that mistreatment'. But it also sometimes requires a court to make an order that has fiscal implications - the court may order, for example, that conditions of detention be improved.

As for shelter, sometimes it also requires a court to simply say - 'no, you cannot evict that tenant', or 'stop that harassment'. And sometimes it will also require a court to make an order that has fiscal implications - it may order, for example, that a homeless person is offered a bed in a shelter.

Crucially, both the prohibition against inhumane treatment and the right to adequate shelter consist of various elements - some of which have fiscal implications and some do not.

The sleight of hand takes place when one element of one right is compared with a different element of the other right.

In other words, the element of inhumane treatment that does not have fiscal implications is compared with the element of shelter that has fiscal implications. And then the conclusion is erroneously reached that inhumane treatment is suitable for judicial scrutiny, while shelter is not. And this conclusion is then generalised from inhumane treatment to all civil and political rights - and from shelter to all economic, social and cultural rights.

Clearly, this logic is flawed.

So my plea is simple: compare like with like. Not apples with oranges. Not Australian Rules with soccer. And not one element of a civil and political right with a different element of an economic, social and cultural right.

However, I think it is also unhelpful and misleading when some advocates of economic, social and cultural rights argue that economic, social and cultural rights and civil and political rights are identical and should be approached in precisely the same way. It seems to me that is too simplistic. 
We must recognise one inescapable difference between these two sets of rights. Over centuries, civil and political rights have generated a deep and dense jurisprudence. The same cannot be said for economic, social and cultural rights. Yes, they too derive from the inherent well-being and dignity of our shared humanity. Yes, they too are enshrined in legally binding international treaties. Yes, they too are justiciable. But it seems to me we have to recognise that their jurisprudence is shallower than that of civil and political rights - and very naturally this may lead to legitimate questions and doubts that should not be brushed aside, but taken seriously.

As I argued earlier, the jurisprudence of economic, social and cultural rights is deepening by the year - but it remains shallower than that of civil and political rights.

There are other challenges, too.

Broadly speaking, there are two ways of vindicating human rights, including economic, social and cultural rights.

One way is via the courts and tribunals (the 'judicial' approach). Another approach is by bringing human rights to bear upon policy-making processes so that policies are put in place that promote and protect human rights (the 'policy' approach). Of course, the two approaches are intimately related and mutually reinforcing. Nonetheless, the distinction between them is important because the 'policy' approach opens up challenging new possibilities for the realisation of human rights.

Lawyers have played an indispensable role in developing the standards that today constitute international human rights law. Naturally, when it comes to the 'judicial' and 'policy' approaches, some lawyers are professionally drawn to the 'judicial' approach. And, of course, this approach has a vital role to play.

In addition to the 'judicial' approach, however, it is also vital that human rights are brought to bear upon all relevant policy-making processes, including those for the reduction and elimination of poverty. 
Significantly, the 'policy' approach depends upon techniques and tools that are not usually in a lawyer's brief case or repertoire. Also, it demands close cooperation amongst a range of disciplines and policy experts. Also, the 'policy' approach demands vigilant monitoring and accountability, but the accountability does not have to be judicial. It could, for example, take the form of publicly available rigorous human rights impact assessments that check whether or not the relevant policy has delivered positive human rights outcomes consistent with the state's legal commitments.

What are the implications of a policy approach?

If I visit a Minister of Health and urge her to introduce policies that reflect her Government's international right to health obligations and she asks me how that is to be done - if my reply only draws upon the traditional human rights skills and techniques, such as 'naming and shaming', letter writing campaigns, threatening her with test cases, and uttering slogans - frankly, she will show me the door, and rightly so.

The judicial approach and the policy approach are both vital - but the policy approach demands new human rights skills, techniques and approaches that will enable us to engage with local, national and international policy makers. For example, if we are serous about monitoring the progressive realisation of economic, social and cultural rights, we have no alternative but to get to grips with indicators and benchmarks. ${ }^{12}$ If we are serious about integrating human rights into policy making, sooner or later we will have to devise a methodology for human rights impact assessments, namely a tool that enables a government to assess the likely impact of a proposed policy on the enjoyment of (say) the right to health, especially for those who are living in poverty. ${ }^{13}$

We should not be discouraged by this but take heart because it is a sign that the human rights movement continues to develop and mature.

\footnotetext{
${ }^{12}$ For example, see my report to the UN Commission on Human Rights setting out a human rights based approach to health indicators, E/CN.4/2006/48, 3 March 2006.

${ }^{13}$ See Paul Hunt and Gillian MacNaughton, Impact Assessments, Poverty and Human Rights: A Case Study Using the Right to the Highest Attainable Standard of Health, 2006 (forthcoming).
} 
And this is why Melbourne's Human Rights Law Resource Centre is so crucial. The Centre provides a place to learn about international law and practice, as well as the experiences of other national jurisdictions. It embraces all human rights - civil, political, economic, social and cultural rights. It is attune to both the judicial approach and the policy approach. It can help the community grasp complex and controversial human rights issues - a couple of which I have mentioned tonight.

An organisation of the future, the Centre richly deserves our sustained support.

$* * * * *$ 